\title{
SCREENING FOR EXTENDED-SPECTRUM BETA-LACTAMASES PRODUCING ESCHERICHIA COLI ISOLATES IN FISH SAMPLE AND PROFILING FOR ANTIBIOTICS SUSCEPTIBILITY
}

\author{
Ananya Choudhury ${ }^{I}$, Mitul Nath ${ }^{1}$, Udaya Kumar Vandana ${ }^{2}$, Diwakar Kumar $^{1} *$ \\ Address (es): \\ ${ }^{1}$ Department of Microbiology, Assam University, Silchar-788011, Assam, India. \\ ${ }^{2}$ Department of Biotechnology, Assam University, Silchar-788011, Assam, India. \\ *Corresponding author: diwakar11@gmail.com \\ Cor

\section{ABSTRACT}

https://doi.org/10.36547/be.2021.4.1.25-29

At present, extended-spectrum $\beta$-lactamase (ESBL)-producing Escherichia coli and other species of Enterobacteriaceae have emerged as a matter of utmost concern. Indiscriminate utilization of antimicrobials in aquaculture generates selective pressure creating reservoirs of drug-resistance genes in fish pathogens and other bacteria, which may disseminate by horizontal gene transfer and reach human pathogens. The present study aims to detect extended-spectrum beta-lactamases (ESBL) production by enterobacteria isolated from locally harbored and imported fresh and dry fishes.

Out of 235 fish samples investigated, the observed incidence of 9.78\% (n=23) E. coli isolates. PCR detection of extended-spectrum $\beta$-lactamase (ESBL)-producing Escherichia coli using primers specific for Bla-TEM, Bla-SHV, Bla-CTX-M. As per molecular detection by Multiplex PCR, 11 isolates exhibited Bla-TEM+CTX-M $M^{+} S H V$ genes, and two isolates exhibited the presence of TEM genes only. Antimicrobial susceptibility patterns against 12 antibiotics were studied, where it was observed that resistance to the selected drug ranges from $4.34 \%$ to $73.9 \%$ for 12 different antibiotics.

Keywords: ESBL, E. coli, fish, antimicrobial susceptibility, Multidrug resistance

\section{INTRODUCTION}

The current era, where people are developing more obsessions for healthy living, has gained safety standards and microbiological attributes of various food items huge attention, which tends to expand at a very gradual pace (Patterson 2012). Fish serve as a convenient and safe source of essential nutrients-proteins, vitamins, and minerals, making itself an interim part of the staple diet, supplementing the maximal part of all nutrient needs (Abdullahi et al., 2001).

Numerous studies have been conducted in various parts of India by researchers to check the bacteriological quality of freshly landed and retail market fish and other seafood (Lakshmanan et al., 1988). Reports have emerged about the deplorable quality of fishes available in domestic markets that are mostly contaminated by pathogenic microorganisms compared to export quality (Nambiar et al., 1990). The contamination of water bodies and estuaries by fecal contamination due to poor sanitary conditions and activities by the adjoining populations and deposition of untreated sewages is emerging as one of the alarming issues concerning fishes' quality calls for strict vigilance and maintenance (Patterson, 2012). The low maintenance and unhygienic conditions of the landing and storage centers and market places exacerbate poor hygiene and consumer safety of fishes (Kumar et al., 2005).

Escherichia coli is widely distributed in the environment as a dominant and innoxious gut flora of humans and animals. In contrast, certain strains of E. coli acquire pathogenicity via procuring virulence factors or through the spread of resistant genes causing intestinal and extraintestinal infections (Bielaszewska $\boldsymbol{e t}$ al., 2011), diarrheal infections, gastroenteritis (Jawetz et al., 1984; Levine, 1987), posing a threat of transferring antibiotic resistivity to other clinically essential strains (Kumar, 2017). E. coli strains pathogenic towards human beings have evolved as a significant cause of a wide range of diseases than any other pathogenic organism (Nataro and Kaper, 1998; Paton and Paton, 1998).

Due to poor hygiene in the rapidly blooming fish farming and harvesting sector (Sapkota et al., 2008), extensive use of antimicrobial agents potentially contributes to increased resistant strains (Benbrook, 2002), threatening humankind, impacting fish farming and their environment. Also, irrational use, coupled with the transmissibility of resistance, marks the emergence of new ESBL producing E. coli (Cantos et al., 2016).

Emergence and desiccation of ESBL producing Enterobacteriaceae since the last decade (Bradford, 2001; Paterson \& Bonomo, 2005; Bush, 2008; Ozcakar et al., 2011) along with the emergence of Multidrug resistance (MDR) among such strains are rising as an alarming rate (Cheng et al., 2014). Prevalence of ESBL producing E. coli strains has been witnessed in most livestock-oriented foods and food products - meat, chicken, fish, raw milk, and milk products (CLSi, 2006; Egea et al., 2012; FSSAI, 2012; Elhadi and Alsamman, 2015). Reports about fish being the reservoir of ESBL producing $E$. coli strains have also been found in China (Jiang et al., 2012). Explicitly, extended-spectrum Beta-Lactamases are enzyme coded by plasmid confined within strains with a four-membered ring, making them capable of inactivating a broad range of $\beta$-lactam antibiotics broadspectrum monobactams and cephalosporin (Bush et al., 1995; Paterson \&
Bonomo, 2005). Numerous research has revealed the emergence of ESBLs as mutations in Sulphydryl variable (bla-SHV), Temoneira (bla-TEM) genes followed by substitution mutation in the active site the protein level producing TEM and SHV type of E. coli. Certain strains also synthesize an additional enzyme CTX-M (Cefotaximase-Munchen), producing bla-CTX-M (Manoharan et al., 2011), which is more active against $3 \mathrm{G}$ Chephelosporin antibiotics, i.e., cefotaxime and ceftriaxone, than ceftazidime. However, point mutations could increase their action against ceftazidime too. CTX-M has been extensively described in different livestock animals and food products recognized as a reservoir of ESBL producing E. coli strains (Carattoli, 2008; Geser et al., 2011; Egea et al., 2012). Numerous reports have suggested that antibiotic resistance genes (bla-CTX-M, bla-SHV, bla-TEM) mostly divulge via food chains or by through interaction with humans and animals (Oppegaard et al., 2001; Winokur et al., 2001; Mesa et al., 2006; Egea et al., 2012) making the microbiological well-being of edibles-fish and fish produces a point of concern all over the world (FAO, 2010).

The threat due to enteric pathogens in fishes becomes more confounding when such bacteria are multidrug-resistant as there is no data available about antibiotic sensitivity pattern related to ESBL-producing bacteria in aquaculture products in Silchar, Assam, India. The current study was intended to detect the occurrence of E. coli, observing the antimicrobial susceptibility, presence of Multidrug resistance, and finally genotypic characterization of the isolates to check the prevalence of ESBL producing E. coli in the fishes procured from local retail and wholesale outlets in Silchar, Assam, India.

\section{MATERIAL AND METHODS}

\section{Sample collection}

In the present study, 235 samples of fishes were randomly taken from Silchar's various retail and wholesale markets during May-July, 2018. The samples were collected in sterile sample bags using sterile hand gloves and were immediately transported to the laboratory in a refrigerated container and processed for bacterial isolation within 24 hours.

\section{Bacterial isolation and analysis}

Aseptically procured samples were gently washed with distilled $\mathrm{H}_{2} \mathrm{O}$ and $5 \mathrm{~g}$ of sample added to $45 \mathrm{ml}$ of Alkaline Peptone Water and incubated overnight at $37^{\circ} \mathrm{C}$ followed by streaking onto Eosin Methylene Blue Agar (Hi media) plates; nucleated colonies showing green metallic sheen were subcultured on MacConkey Agar For selective and differential isolation of E. coli. Suspected colonies were confirmed by the IMViC test (Montenegro et al., 1990). Biochemically confirmed isolates were stored in Luria broth: glycerol (1:1) stock at $-20^{\circ} \mathrm{C}$ for further analysis. 


\section{Antimicrobial susceptibility testing}

Antimicrobial susceptibility testing was accomplished in accord with CLSI guidelines. Antimicrobial agents were tested against the isolates following KirbyBauer's disc diffusion technique on Mueller-Hinton agar plates, and plates were incubated overnight at $37^{\circ} \mathrm{C}$. Distinct regions of inhibition were measured in $\mathrm{mm}$ and deciphered into Susceptible (S), Intermediate (I), and Resistant (R) groupings as per NCCLS guidelines. Antibiotics and their potencies used are listed in table 1.

Table 1 antibiotics and their potencies used in the study.

\begin{tabular}{ll}
\hline Antibiotics & Potencies $(\mathbf{m c g})$ \\
\hline Ampicillin & 10 \\
Amikacin & 10 \\
Cefotaxime & 10 \\
Ciprofloxacin & 10 \\
Gentamicin & 50 \\
ImipenemEDTA & $10 / 10$ \\
Streptomycin & 25 \\
Ofloxacin & 2 \\
Ceftriaxone & 30 \\
Cefepime & 30 \\
Piperacillin/Tazobactam & $100 / 10$ \\
Meropenem & 10 \\
Ampicillin/Sulbactam & $10 / 10$ \\
Levofloxacin & 5 \\
\hline
\end{tabular}

\section{Detection of ESBL production}

Isolates exhibiting a diameter of less than $27 \mathrm{~mm}$ for Cefotaxime and less than 25 $\mathrm{mm}$ for Ceftriaxone in antibiotic sensitivity testing were subjected to ESBL production test as per Modified Double Disc Synergy test, by placing a disc of Amoxicillin-Clavulanate $(20 / 10 \mathrm{mcg})$ at the center along with three Cephalosporins viz, Cefotaxime and Ceftriaxone (3GC), Cefepime (4GC), $15 \mathrm{~mm}$ and $20 \mathrm{~mm}$ away respectively from center to center of Amoxicillin-Clavulanate disc on a lawn culture of test organism on MHA plates (as per CLSI guidelines) and observed for any contortions or growth of zone of inhibition to the Amoxicillin-Clavulanate disc.

\section{DNA extraction}

Genomic DNA was isolated from $5 \mathrm{ml}$ of LB broth culture as per the manufacturer's protocol (Genomic DNA Miniprep Kit, mdi Membrane Technologies (India), and extracted DNA was stored at $-20^{\circ} \mathrm{C} .1-2 \mu \mathrm{l}$ of genomic DNA (200ng/ $\mu$ l) was used as a template for PCR, according to Ozpinar $\boldsymbol{e t}$ al. (2013).

\section{Polymerase chain reaction}

For amplification of $\beta$-Lactamase genes, oligonucleotide primers of Bla-TEM, Bla-SHV, and Bla-CTX-M were used (Ozpinar et al., 2013). PCR was performed in $25 \mu 1$ reaction mixture containing $2.5 \mu 1$ of Taq buffer $(10 \mathrm{X}), 0.5 \mu 1 \mathrm{dNTPs}$ $(10 \mu \mathrm{m}), 1 \mu \mathrm{l}$ of each primer (10 picomoles), $2 \mu 1$ of template DNA (200ng $/ \mu \mathrm{l}), 1$ unit of Taq DNA Polymerase (NEB), and sterile MQ $\mathrm{H}_{2} \mathrm{O}$ were used to make the final volume of $25 \mu$. PCR was performed for 32 cycles at $95^{\circ} \mathrm{C}$ for 5 minutes
(Initial denaturation), $95^{\circ} \mathrm{C}$ for 45 seconds (Denaturation), $52.4^{\circ} \mathrm{C}$ for 45 seconds (Annealing), $72^{\circ} \mathrm{C}$ for 1 minute (Extension), and a final extension at $72^{\circ} \mathrm{C}$ for 7 minutes. Amplified PCR products were resolved in 1\% Agarose gel.

\section{RESULTS AND DISCUSSION}

Screening of a total of 235 fish samples, including freshly harbored, dried and inland-imported fish, exhibited an overall incidence of $9.78 \% \quad(\mathrm{n}=23)$ biochemically confirmed E. coli isolates (Table 2).

A similar study comprising raw fish samples and ready to eat fish products from Ludhiana, India, revealed an overall incidence of 47 and 7 E. coli isolates from raw fishes and ready to eat fish products, respectively (Gupta et al., 2012). A study carried out by Kumar et al. (2005) revealed that $38.8 \%$ of finfish samples from the fresh fish market and $25 \%$ from landing centers were confirmed as $E$. coli isolates. A study performed by Thampuran et al. (2005) in Veraval district of Gujarat on seafood from the retail fishery outlets for the prevalence of ESBL fabricating $E$. coli revealed the occurrence of Escherichia coli isolates in 28 samples out of 238 , i.e., approx $12 \%$, firmly supporting the findings of the current study. From a study carried out by Dutta et al. (2016) to find out the prevalence of $E$. coli in shrimps and fishes sold in retail markets at Kolkata, India kept forward the occurrence of the bacteria in $80.70 \%$, i.e., 138 samples out of 171 studied samples using standard microbiological and biochemical tests. Ryu et al. (2012) studied during the period 2005 to 2008 based on 2663 marine products sold in Seoul's retail and wholesale markets, Korea revealed $179(6.7 \%)$ samples as the bearer of the concerned organism supporting the findings of the current study. Jeyasanta et al. (2012) studied a total of 168 samples collected from the main landing centers of intertidal and fish markets of Tuticorin coast, out of 128 samples appearing to be positive for the presence of fecal coliform, 91, i.e., $71.8 \%$ of the value appeared as positive as E. coli.

Table 2 Incidence of $E$. coli in fresh and dry fish samples from various Silchar markets

\begin{tabular}{lccc}
\hline $\begin{array}{l}\text { Area of the collected } \\
\text { sample }\end{array}$ & $\begin{array}{c}\text { No of the } \\
\text { samples } \\
\text { collected }\end{array}$ & $\begin{array}{c}\text { Incidence of } \\
\boldsymbol{E} \text {. coli in } \\
\text { samples }\end{array}$ & $\begin{array}{c}\text { \% of } \boldsymbol{E} \text {. coli in } \\
\text { the samples }\end{array}$ \\
\hline Ithkhola Market & 55 & 3 & 5.45 \\
National Highway & 50 & 2 & 4 \\
Market & 31 & 0 & 0 \\
Madhuraghat Market & 32 & 3 & 9.37 \\
Door-to-door vendors & 12 & 5 & 41.66 \\
NH Chourangi Market & 21 & 3 & 14.28 \\
Fhatakbazar Market & 18 & 4 & 22.22 \\
Annapurna & 16 & 3 & 18.75 \\
market+Sanjay Market & $\mathbf{2 3 5}$ & $\mathbf{2 3}$ & $\mathbf{9 . 7 8}$ \\
College Road Market + & & & \\
SMC Market & & & \\
Total & & &
\end{tabular}

\section{Antibiotic Susceptibility Pattern of $E$. coli isolates}

In the current study, antimicrobial susceptibility patterns contrary to 12 antibiotics were studied for $23 \mathrm{E}$. coli isolates where it was observed that resistance to the selected drug tested ranges from $4.34 \%$ to $73.9 \%$ for 12 different antibiotics. In-vitro antimicrobial susceptibility test results have been noted in Table 3. Furthermore, out of 23 positive isolates, 11 showed resistance to more than two antibiotics used in the susceptibility assay and can be considered Multidrug-Resistant (MDR). 
Table 3 In-vitro antimicrobial susceptibility test result

\begin{tabular}{lcccccc}
\hline Antibiotics & $\begin{array}{c}\text { No. of } \\
\text { resistant } \\
\text { isolates }\end{array}$ & $\begin{array}{c}\text { Percentage } \\
\text { of resistant } \\
\text { isolates }\end{array}$ & $\begin{array}{c}\text { No. of } \\
\text { susceptible } \\
\text { isolates }\end{array}$ & $\begin{array}{c}\text { Percentage of } \\
\text { susceptible } \\
\text { isolates }\end{array}$ & $\begin{array}{c}\text { No. of } \\
\text { intermediately } \\
\text { resistant isolates }\end{array}$ & $\begin{array}{c}\text { Percentage of } \\
\text { intermediately } \\
\text { resistant isolates }\end{array}$ \\
\hline Ampicillin & 16 & 69.6 & - & - & 07 & 30.5 \\
Amikacin & 01 & 4.3 & 22 & 95.7 & - & - \\
Cefotaxime & 12 & 52.2 & 08 & 34.8 & 03 & 13 \\
& 10 & 43.5 & 11 & 47.8 & 02 & 8.7 \\
Ciprofloxacin & 5 & 21.8 & 15 & 65.2 & 03 & 13 \\
Gentamicin & 01 & 4.3 & 22 & 95.7 & - & - \\
Imipenem EDTA & - & - & 23 & 100 & - & 8.7 \\
Streptomycin & 15 & 65.2 & 06 & 26.1 & 02 & 26 \\
Ofloxacin & 11 & 47.8 & 06 & 26.1 & 06 & 8.7 \\
Ceftriaxone & 15 & 65.2 & 06 & 26.1 & 02 & 4.3 \\
Cefepime & 13 & 56.6 & 09 & 39.1 & 01 & - \\
Piperacillin/Tazobactam & 17 & 73.9 & 05 & 21.8 & 01 & -3 \\
Meropenem & 03 & 13 & 20 & 87 & - & 13 \\
Ampicillin/Sulbactam & 05 & 21.8 & 15 & 65.2 & 03 & \\
Levofloxacin & & & & &
\end{tabular}

A study based on finding $E$. coli in the meat of shrimp, fish, chicken, and mutton at Vishakhapatnam, Andhra Pradesh, reported massive E. coli presence in the samples and $90 \%$ resistance towards ampicillin (Chakravarty et al., 2015). In the study of Veraval, Gujarat, the 28 samples found to be positive as E. coli when subjected to antibiotic sensitivity checking showed the highest rate of resistance towards ampicillin (39.29\%), 11 samples appeared as MDR. In contrast, 4 (14.29\%) were confirmed as ESBL producers, supporting the findings of the current study of 16 out of 23 , i.e., $69.56 \%$ of $E$. coli isolates being resistant to ampicillin, 12 being MDR, and 14 being ESBL producers (Sivaraman et al., 2017). Ryu HS et al. (2012) study showed the highest resistance towards tetracycline $(30.7 \%)$ and lowerest towards ampicillin $(6.7 \%)$, contradicting the findings of the current study. In a study conducted by Kumar $\boldsymbol{e t}$ al. (2005), wherein 116 samples of E. coli were treated with 14 different antibiotics, seven samples were observed to be resistant to more than five antibiotics, whereas 1 sample resistant to 8 antibiotics establishing shreds of evidence for the existence of Multidrug-resistant E. coli in seafood of India. A study by Jeyasanta et al. (2012) involving 168 E. coli samples collected from the Tuticorin coast's fish markets was tested for drug susceptibility against 15 antibiotics; 11 isolates exhibited multiple resistance to 4 while one isolate revealed resistance against five antibiotics.

\section{Polymerase chain reaction}

Multiplex PCR was performed to examine the presence of $\beta$-Lactamase genes in 23 E. coli isolates; Bla- $\boldsymbol{T E M}+\boldsymbol{C T} \boldsymbol{X}-\boldsymbol{M}+\boldsymbol{S H} \boldsymbol{V}$ genes were present in 11 isolates; two isolates were harboring only $\boldsymbol{T E M}$ genes. Results are listed in Table 4 and Figure 1.

Table 4 Frequency of occurrence of ESBL genes in E. coli isolates

\begin{tabular}{|c|c|c|c|c|c|c|c|c|c|}
\hline $\begin{array}{l}\text { Market } \\
\text { area }\end{array}$ & $\begin{array}{c}\text { No of } E \text {. coli } \\
\text { isolates }\end{array}$ & Bla-TEM & $\begin{array}{c}\% \text { of Bla- } \\
\text { TEM }\end{array}$ & Bla-SHV & $\begin{array}{l}\text { \% of Bla- } \\
\text { SHV }\end{array}$ & $\begin{array}{c}\text { Bla- } \\
\text { CTX-M }\end{array}$ & $\begin{array}{l}\text { \% of Bla- } \\
\text { CTX-M }\end{array}$ & $\begin{array}{c}\text { Bla- TEM+ } \\
\text { CTX-M+ } \\
\text { SHV }\end{array}$ & $\begin{array}{c}\text { \% of Bla- TEM+ } \\
\text { CTX-M+ } \\
\text { SHV }\end{array}$ \\
\hline Ithkhola Market & 3 & 2 & 66.6 & 1 & 33.3 & 1 & 33.3 & 1 & 33.3 \\
\hline $\begin{array}{l}\text { National } \\
\text { Highway Market }\end{array}$ & 2 & 1 & 50 & 1 & 50 & 1 & 50 & 1 & 50 \\
\hline $\begin{array}{l}\text { Madhuraghat } \\
\text { Market }\end{array}$ & 0 & 0 & - & 0 & - & 0 & - & 0 & - \\
\hline $\begin{array}{l}\text { Door-to-door } \\
\text { vendors }\end{array}$ & 3 & 1 & 33.3 & 1 & 33.3 & 1 & 33.3 & 1 & 33.3 \\
\hline $\begin{array}{l}\text { NH Chourangi } \\
\text { Market }\end{array}$ & 5 & 3 & 60 & 2 & 40 & 2 & 40 & 2 & 40 \\
\hline $\begin{array}{l}\text { Fhatakbazar } \\
\text { Market }\end{array}$ & 3 & 1 & 33.3 & 1 & 33.3 & 1 & 33.3 & 1 & 33.3 \\
\hline $\begin{array}{l}\text { Annapurna } \\
\text { market+Sanjay } \\
\text { Market }\end{array}$ & 4 & 3 & 75 & 3 & 75 & 3 & 75 & 3 & 75 \\
\hline $\begin{array}{l}\text { College Road } \\
\text { Market + SMC } \\
\text { Market }\end{array}$ & 3 & 2 & 66.6 & 2 & 66.6 & 2 & 66.6 & 2 & 66.6 \\
\hline Total & 23 & 13 & 56.5 & 11 & 47.8 & 11 & 47.8 & 11 & 47.8 \\
\hline
\end{tabular}




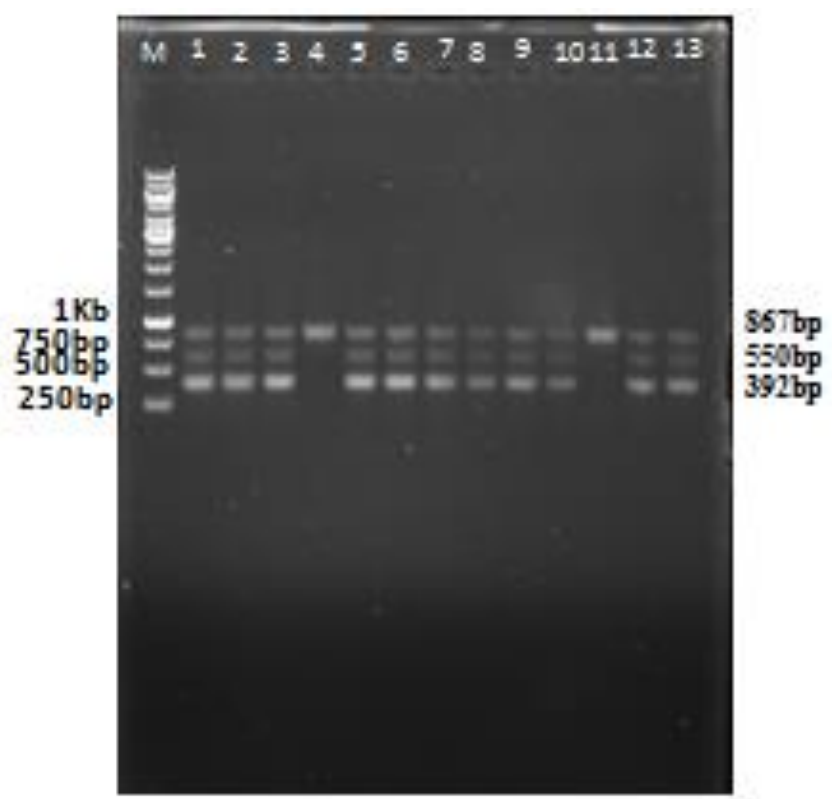

Figure 1 Presence of TEM, SHV, CTX-M gene in E. coli by multiplex PCR. Lane 1:1 kb ladder, lane 2-13 isolates.

\section{CONCLUSION}

The present study outcomes indicate a moderate E. coli in fish samples procured from Silchar's different markets. Further analysis indicated a wide variation in their antibiotic sensitivity, along with exhibiting the incidence of a few multidrug-resistant strains and a wide occurrence of ESBL genes (bla-TEM, blaSHV, and bla-CTX-M). This indicates the necessity to understand the need to suppress human pathogens, the judicious use of antibiotics in aquaculture farms and import lots, substantial level oligotrophication of the water bodies, and finally, the need to bring these regulatory and educational efforts into action to maintain safety and quality of both fishes and the consumers.

Conflict of interest: The authors declare that no conflict of interest exists.

Acknowledgment: We express our sincere gratitude to Dr. Amitabha Bhattacharjee for providing us the oligonucleotides used in the study.

\section{REFERENCES}

Abdullahi, S.A., Abolude, D.S., Ega, R.A. 2001. Nutrient quality of four oven dried fresh water cat fish species in Northern Nigeria. J. Trop. Biosci., 1, 70-76. Alexander, M. 1971. Microbial ecology. John Wiley \& Sons, New York, N. Y. x $+511 \mathrm{pp}$.

Benbrook, C.M. 2002. "Antibiotic drug use in U.S. aquaculture. Institute for Agriculture and Trade Policy, Washington, USA.

Bradford, P.A. 2001. Extend-spectrum beta-lactamases in the $21^{\text {st }}$ century: characterization, epidemiology, and detection of this important resistance threat. Clin. Microbiol. Rev., 14(4), 933-951. https://doi.org/10.1128/CMR.14.4.933951.2001

Bush, K., Jacoby, G.A., Medeiros, A.A. 1995. A functional classification scheme for beta-lactamases and its correlation with molecular structure. Antimicrob. Agents Chemother., 39(6), 1211-1233. https://doi.org/10.1128/aac.39.6.1211

Bush, K. (2008). Extended-spectrum beta-lactamases in North America, 19872006. Clin. Microbiol. Infect. 14 Suppl 1, 134-143. https://doi.org/10.1111/j.1469-0691.2007.01848.x

Cantas, L., Suer, K., Guler, E., \& Imir, T. 2016. High Emergence of ESBLProducing E. coli Cystitis: Time to Get Smarter in Cyprus. Frontiers in microbiology, 6, 1446. https://doi.org/10.3389/fmicb.2015.01446

Carattoli, A. 2008. Animal reservoirs for extended spectrum beta-lactamase producers. Clin. Microbiol. Infect., 14 Suppl 1, 117-123. https://doi.org/10.1111/j.1469-0691.2007.01851.x
Chakravarty, S.M., Ganesh, C. R. P., Amarnath, D., Sudha, S.B., Subhashini, M. 2015. Escherichia coli - occurrence in meat of shrimp,fish,chicken and mutton and its antibiotic resistant. European Journal of Experimental Biology, 2015, 5(7), 41-48

Cheng, G., Hao, H., Xie, S., Wang, X., Dai, M., Huang, L., \& Yuan, Z. (2014). Antibiotic alternatives: the substitution of antibiotics in animal husbandry?. Frontiers in microbiology, 5, 217. https://doi.org/10.3389/fmicb.2014.00217

Clinical and Laboratory Standards Institute (CLSI). 2015. Performance standards for antimicrobial susceptibility testing; approved standard; 25th informational supplement. CLSI document M100-S25. Clinical and Laboratory Standards Institute, Wayne, PA

Dutta, C., Sengupta, C. 2016. Prevalence of Escherichia coli in Fish and Shrimps obtained from Retail Fish Markets in \& around Kolkata, India, Frontiers in Environmental Microbiology, Vol. 2, No. 1, 1-5. https://doi.org/10.11648/j.fem.20160201.11

Egea, P., Lopez-Cerero, L., Torres, E., Gomez-Sanchez, C.M., Serrano, L., Navarro Sanchez, M.D., Rodriguez J.B., Pascual A. 2012. Increased raw poultry meat colonization by extended spectrum beta-lactamase- producing Escherichia coli in the South of Spain. Int. J Food Microbiol., 159(2), 6973. https://doi.org/10.1016/j.ijfoodmicro.2012.08.002

Elhadi, N., Alsamman K. 2015. Incidence and antimicrobial susceptibility pattern of extended-spectrum- $\beta$-lactamase-producing Escherichia coli isolated from retail imported mackerel fish. Afr. J. Biotechnol., 14(23), 1954-1960. https://doi.org/10.5897/AJB2015.14698

FAO. 2010. The state of world fisheries and aquaculture 2010. Rome: FAO Fisheries and Aquaculture Department; $197 \mathrm{p}$.

FSSAI (Food Safety and Standards Authority of India). 2012. Meats \& Meat products Manual of Methods of Analysis of Foods. Lab Manual-6, 1-79.

Geser, N., Stephan. R., Kuhnert, P., Zbenden, R., Kaeppeli, U., Cernela, N., Heachler, N. 2011. Fecal carriage of extended-spectrum $\beta$ - lactamase-producing Enterobacteriac-eae in swine and cattle at slaughter in Switzerland. J. Food Prot., 74(3), 446-449. https://doi.org/10.4315/0362-028X.JFP-10-372

Kumar, H.S., Parvathi, A., Karunasagar, I. et al. 2005. Prevalence and antibiotic resistance of Escherichia coli in tropical seafood. World $J$ Microbiol Biotechnol, 21, 619-623. https://doi.org/10.1007/s11274-004-3555-8

Iyer, T.S.G., Damle, S.P., Garg, D.K., Nambiar, V.N., Vasu, N.M. 1986. Quality of fish in retail markets of Bombay. Fishery technology, 23(1), 78-83.

Jawetz, E., Melnick J., Adelberg, E.A. 1984. Review of Medical Microbiology, 16th ed. Los Altos, California: Long Medical Publication, 122-144.

Jeyasanta, K I., Aiyamperumal, V., Patterson, J. 2012. Prevalence of Antibiotic Resistant Escherichia coli in Sea Foods of Tuticorin Coast, Southeastern India. $\begin{array}{lllll}\text { Advances in Biological Research, } 6 \text { (2), } & \text { 70-77. }\end{array}$ https://doi.org/10.5829/idosi.abr.2012.6.2.6475

Jiang, H.X., Tang, D., Liu, Y.H., Zhang, X.H., Zeng, Z.L., Xu, L., Hawkey, P.M. 2012. Prevalence and characteristics of b-lactamase and plasmidmediatedquinolone resistance genes in Escherichia coli isolated from farmed fish in China. J. Antimicrob. Chemother. 67(10), 2350-2353. https://doi.org/10.1093/jac/dks250

Kumar, S., Singh, A.S., Lekshmi, M., Prakasan, S., Nayak, B.B. 2017. Multiple Antibiotic-Resistant, Extended Spectrum- $\beta$-Lactamase (ESBL)-Producing Enterobacteria in Fresh Seafood. Microorganisms, 5(3), 53 https://doi.org/10.3390/microorganisms5030053

Lakshmanan, P.T., Mathen, C., Varma, P.R.G., Iyer, T.S.G. 1984. Assessment of quality of fish landed at the cochin fisheries harbour. Fish. Technol., 21: 98-105.

Levine,M.M. 1987. Escherichia coli that cause diarrhea:enterotoxigenic,enteropathogenic, enteroinvasive, enterohemorrhagic and enteroadherent. J. Infect. Dis., 155(3), 377-389. https://doi.org/10.1093/infdis/155.3.377

Manoharan, A., Premalatha, K., Chatterjee, S., Mathai, D., Sari Study Group. 2011. Correlation of TEM, SHV and CTX-M extended-spectrum beta lactamases among Enterobacteriaceae with their in vitro an-timicrobial susceptibility. Indian J. Med. Microbiol., 29(2), 161-164. https://doi.org/10.4103/0255-0857.81799 Mesa, R.J., Blanc, V., Blanch, A.R., Cortés, P., González, J.J., Lavilla, S., Miró, E., Muniesa, M., Saco, M., Tórtola, M.T., Mirelis, B., Coll, P., Llagostera, M., Prats, G., Navarro, F. 2006. Extended-spectrum beta-lactamase producing Enterobacteria-ceae in Different environments (humans, food, animal farms and sewage). J. Antimicrob. Chemother., 58(1), 211-215. https://doi.org/10.1093/jac/dkl211 
Nambiar, V.N., Iyer, K.M. 1990. Microbial quality of fish in retail trade in cochin. Fish. Technol., 27, 51-59.

Nataro, J.P., Kaper, J.B. 1998. Diarrheagenic Escherichia coli. Clinical Microbiology Reviews., 11(1), 142-201. https://doi.org/10.1128/CMR.11.1.142

Oppegaard, H., Steinum, T.M., Wasteson, Y. 2001. Horizontal transfer of a multidrug resistance plasmid between coliform bacteria of human and bovine origin in a farm environment. Appl. Environ. Microbiol., 67(8), 37323734. https://doi.org/10.1128/AEM.67.8.3732-3734.2001

Ozcakar, Z.B., Yalcinkaya, F., Kavaz, A., Kadioglu, G., Elhan, A.H., Aysev, D. 2011. Urinary tract infections owing to ESBL-producing bacteria: microorganisms change-clinical pattern does not. Acta Paediatr., 100(8), e61-4. https://doi.org/10.1111/j.1651-2227.2011.02262.x

Paterson, D.L., Bonomo, R.A. 2005. Extended-spectrum -lactamases: a clinical update. Clin. Microbiol. Rev., 18(4), 657-686.

Paton, A.W., Paton, J.C. 1998. Detection and characterisations of shigella toxigenic Escherichia coli by using multiplex PCR assays for stx1, stx2, eaeA, enterohemorrhagic E. coli hlyA, rfbO111 and rfbO157. Journal of Clinical Microbiology, 36(2), 598-602. https://doi.org/10.1128/JCM.36.2.598-602.1998

Ryu, H.S. 2012. Antimicrobial resistance and resistance genes in Escherichia coli strains isolated from commercial fish and sea food. International Journal of Food Microbiology, 152(1-2), 14-18. https://doi.org/10.1016/j.ijfoodmicro.2011.10.003

Sapkota, A., Sapkota, A.R., Kucharski, M., Burke, J., Mckenzie, S., Walker, P., Lawrence, R. 2008. Aquaculture practices and potential human health risks: Current Knowledge and future priorities. Environ. Int., 34(8), 1215-1226. https://doi.org/10.1016/j.envint.2008.04.009

Sivaraman,G.K., Prasad, M.M., Jha, A.K., Visnuvinayagam, S., Renuka,V., Remya.S., Kriplani, Y., Vanik, D. 2017. Prevalence of extended - spectrum betalactamase producing E.coli in seafood from the retail fishery outlets of Veraval, Gujarat, India. Journal of Environmental Biology, 38(4), 523-526. https://doi.org/10.22438/jeb/38/4/MRN-366

Thampuran, A.N., Surendraraj, A., Surendran, P.K. 2005. Prevalance and Characterization of Typical and Atypical Escherichia coli from Fish sold at retail in Cochin,India. Journal of Food Protection, 68(10), 2208-11. https://doi.org10.4315/0362-028x-68.10.2208

Varma, P.R.G. and Iyer, T.S.G. and Mathen, C. 1988. Quality of commercial frozen boiled clam meat. Fishery Technology, 25(1), 36-39.

Winokur, P.L., Vonstein, D.L., Hoffman, L.J., Uhlenhopp, E.K., Doern, G.V. 2001. Evidence for transfer of CMY-2 AmpC beta-lactamase plasmids between Escherichia coli and Salmonella isolates from food animals and humans. Antimicrob. Agents Chemother., 45(10), 2716-2722. https://doi.org/10.1128/AAC.45.10.2716-2722.2001 